Debreceni Egyetem, Fogorvostudományi Kar, Bioanyagtani és Fogpótlástani Tanszék*

Debreceni Egyetem, Fogorvostudományi Kar, Arc-, Állcsont és Szájsebészeti Tanszék ${ }^{* *}$

Debreceni Egyetem, Fogorvostudományi Kar, Gyermekfogászati és Fogszabályozási Tanszék ${ }^{\star \star \star}$

\title{
Fogsor alaplemezből kioldódó allergének kötődésének vizsgálata Fourier-Transzformációs Felületi Plazmon Rezonancia (FT-SPR) módszerrel
}

\author{
BAKÓ JÓZSEF*, DR. KELEMEN MÁTÉ**, DR. SZALÓKI MELINDA*, \\ DR. VITÁLYOS GÉZA***, DR. RADICS TÜNDE*, DR. HEGEDÜS CSABA*
}

\begin{abstract}
A fogászatban az új anyagrendszerek megjelenésével párhuzamosan egyre nagyobb ütemben növekszik a potenciálisan allergiás tünetek kiváltására alkalmas anyagok köre. Az adott allergénnek rendkívül kis mennyisége is képes allergiás reakció kiváltására, ezért kiemelt jelentősége van ezen antigénként szereplő anyagok (például: formaldehid, metakrilsav, benzoil-peroxid) fehérjékhez való kötődési lehetőségeinek vizsgálatának. Ezen sajátosságok vizsgálatára a Fourier-Transzformációs Felületi Plazmon Rezonancia Spektroszkópia (FT-SPR) jól alkalmazható eljárás. A módszer előnyei közé sorolható a kiemelkedő érzékenység, a jelölés nélküli detektálás képessége, valamint a valós idejü vizsgálatok kivitelezésének lehetősége.

Kísérleteink célja a formaldehid és metakrilsav mint a leggyakoribb fogászati allergének közé tartozó anyagok FT-SPR spektroszkópiás vizsgálata volt, kiemelt hangsúlyt fektetve koncentrációfüggő mérések elemzésére és kiértékelésére.

Méréseinket formaldehid és metakrilsav desztillált vizes hígítási soraival végeztük. Eredményeinkkel igazoltuk, hogy az eljárás elméletileg lehetővé teszi az SPR-chip fölött áramoltatott oldat koncentrációjának akár százezrelékes nagyságrendű megváltozásának detektálását is. A koncentrációfüggő vizsgálataink során bizonyítottuk, hogy a módszer kvantitatív meghatározásra is alkalmas. Kísérleteink alapján megállapítható az eljárás széleskörű alkalmazhatósága, amely nagyban megkönnyítheti a biomolekuláris kölcsönhatások jövőbeli feltérképezését és megértését.
\end{abstract}

Kulcsszavak: formaldehid, metakrilsav, allergén, Fourier-Transzformációs Felületi Plazmon Rezonancia Spektroszkópia (FT-SPR)

\section{Bevezetés}

A fogászat szakterületén széles körben használt polimerek (fogsorok alaplemezei, kompozit tömőanyagok stb.) gyakran váltanak ki allergiás reakciókat a pácienseknél $[1,11]$. A fogászatban leggyakrabban alkalmazott polimer a polimetil-metakrilát (PMMA), amely a metakrilsav metilészterének (metil-metakrilát - MMA) polimerje. A monomerek polimerré történő átalakulása azonban nem tökéletes, ezért MMA monomerek maradnak vissza, amelyek a polimerből kioldódhatnak [3, 13, 17]. Az MMA molekulák oxidációjakor formaldehid, hidrolízisekor pedig metakrilsav keletkezik [19]. Ezen molekulák citotoxikusak, emellett fokozott reaktivitásuknak köszönhetöen a leggyakoribb fogászati allergének közé tartoznak $[8,9]$.

A Felületi Plazmon Rezonancia (SPR) spektroszkópia egy olyan detektálási módszer, amelynek segítségével egy a detektorként használt fémfelszín közvetlen közelében, a különböző kötések/kötődések kialakulásának hatására bekövetkező törésmutató-változást lehet nagy pontossággal nyomon követni. A módszer alapja a felületi plazmon rezonanciajelenség, ami egy fém-dielektrikum határfelületen az úgynevezett vezetési elektronok mozgásához kapcsolódó elektronsürüség-hullámok gerjesztésekor következik be. A mérés elvét az biztosítja, hogy ha egy adott fém felületére valamilyen anyag fizikai vagy kémiai úton kötődik, vagy arról leválik, illetve a fém körüli közeg törésmutatója megváltozik, az az adott fém elektronjainak állapotát megváltoztatja. A bekövetkezett változásokat ezzel a technikával különösen nagy érzékenységgel detektálhatjuk [5, 10, 12].

Hagyományos SPR Spektroszkóppal végzett mérések során a fény hullámhosszát állandó értéken tartva vizsgálják a visszavert fénysugár intenzitását a beesési szög változásának függvényében. Minimális reflektancia a rezonanciaszög esetén tapasztalható, amely maximális SPRválaszt vált ki. Az FT-SPR Spektroszkópia lehetővé teszi, hogy az SPR-mérések FT-IR (Fourier-Transzformációs Infravörös Spektroszkópia) platformon, tehát ezen készülékkel egybeépítve kerüljenek kivitelezésre. Ezáltal az FT-IR tulajdonságai - úgymint a nagyfokú érzékenység, a multiplexitás és a változtatható hullámhossz - technikai 
előnyt jelentenek a hagyományos SPR szögeltolódás-mérésekkel szemben. FT-SPR vizsgálatok esetén a beesési szöget fix értéken tartva mérjük a reflektanciát, a fény közeli-infravörös spektrumában. Így kerülnek megállapításra a különböző hullámhossz-tartományokban megjelenő intenzitások, melyekből a kötődések kialakulására vagy bomlására lehet következtetni [6, 7].

A módszer segítségével a biomolekuláris kölcsönhatások kinetikája valós időben nyomon követhető, így a kialakuló vagy felbomló kötések és kötődések azonnal detektálásra kerülnek, azok méréséhez egyéb beavatkozás nem szükséges. Külön előnyös tulajdonság, hogy a molekulák kötődése sem igényel egyéb jelölési feladatot, hanem közvetlenül a kötődés kialakulása biztosítja a mérendő jelet, így az eljárás nagy érzékenysége még a gyenge felületi kölcsönhatások vizsgálatát is lehetóvé teszi. Az FT-SPR Spektroszkópiát más bioanalitikai módszerekkel összehasonlítva (PM-RAIRS, QCM-D), alacsony koncentrációk detektá-

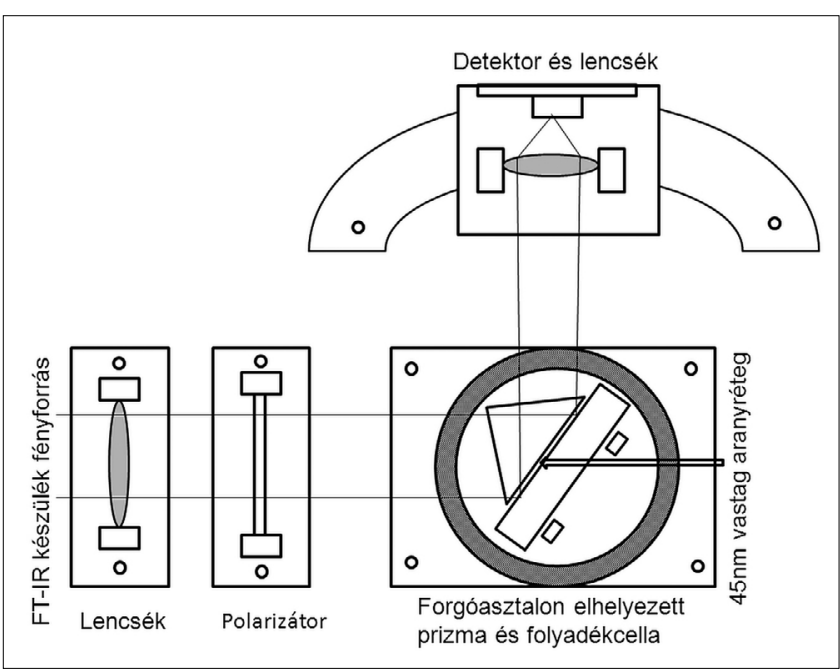

1.a) ábra: FT-SPR készülék sematikus ábrázolása (Kretschmann-elrendezés szerint)

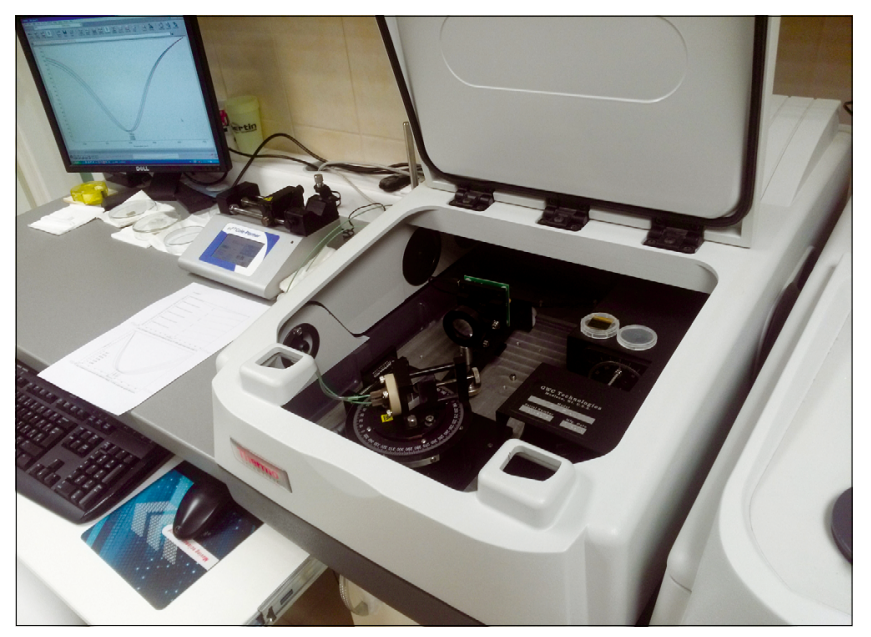

1.b) ábra: Thermo Scientific FT-SPR készülék, SPRTM 100 modul (és a NicoletTM 6700 FT-IR Spektroszkóp) lására egyértelmúen az általunk is használt módszer bizonyult a legnagyobb érzékenységűnek [4]. Az eljárás segítségével különböző biomolekulák speciálisan kezelt biomimetikus felszínhez való kötődését is monitorozhatjuk $[2,15]$. Emellett alkalmas specifikus antigénantitest-kötődések vizsgálatára [16], illetve különböző fehérjék funkcionalizált polimerfelszínnel való kölcsönhatásának nyomon követésére is $[14,18]$.

Jelen kutatásunk célja a formaldehid és a metakrilsav - mint gyakori fogászati allergének - FT-SPR chiphez történő kötődésének vizsgálata, illetve a molekulákkal végzett koncentrációfüggő mérések elemzése és kiértékelése.

\section{Anyag és módszer}

Kísérleteinket formaldehid és metakrilsav hígítási sorokkal végeztük. A Sigma-Aldrich Co. LLC. (St. Louis, MO, USA) által forgalmazott 37\%-os töménységű formaldehid, illetve $99 \%$-os töménységủ metakrilsav-oldatokból $0,01 \%$-os, $0,05 \%$-os, $0,1 \%$-os, $0,15 \%$-os és $0,2 \%$-os koncentrációjú oldatokat készítettünk, oldószerként desztillált vizet használva. A mérések során a háttérspektrumokat desztillált víz segítségével vettük fel.

Méréseinket szobahőmérsékleten végeztük a Thermo Electron Corporation által kifejlesztett (Waltham, MA, USA) SPR ${ }^{\mathrm{TM}} 100$ modult használva, amelyet a Thermo Electron Corporation által gyártott (Waltham, MA, USA) Nicolet ${ }^{\mathrm{TM}} 6700$ FT-IR Spektroszkóppal kapcsoltunk rendszerbe. Fehér fényt kibocsátó wolfram-halogén fényforrást alkalmaztunk kalciumfluorid $\left(\mathrm{CaF}_{2}\right)$ fényosztóval. A prizmához erősített aranyfilm vastagsága $45 \mathrm{~nm}$ volt. A chip felszínéhez egy folyadékcella volt rögzítve; a vizsgált minták szállítása Cole Palmer 110 típusú (EW-74905-04, Hollston, Ma, USA) fecskendő pumpa segítségével történt $0,5 \mathrm{ml} / \mathrm{min}$ sebességgel. Az általunk használt elrendezés elvi vázlata, és maga a berendezés az 1. ábra $a$.) és $b$.) részén kerül bemutatásra. A visszavert fénysugarat egy InGaAs detektorra fókuszáltuk. A kapott adatok feldolgozásához a Thermo Fisher Scientific Inc. (Waltham, MA, USA) által kifejlesztett OMNICTM szoftvercsomagot használtuk.

Minden egyes görbe 16 interferogram átlagolásának eredménye $8 \mathrm{~cm}^{-1}$-es felbontás mellett, az adatpontok távolsága $0,964 \mathrm{~cm}^{-1}$. Mindkét hígítási sorral végzett mérés során meghatároztuk a különböző töménységú oldatok egyéni spektrumait. Az egyéni spektrumok alapján meghatározott rezonanciahullámhossz-értékek segítségével az adott anyaghoz tartozó kalibrációs egyenes meghatározására került sor.

\section{Eredmények}

A 2. ábrán láthatók a formaldehid-oldatok FT-SPR egyéni spektrumai közös diagramon feltüntetve. Az egyes görbék balról jobbra haladva: desztillált víz, 


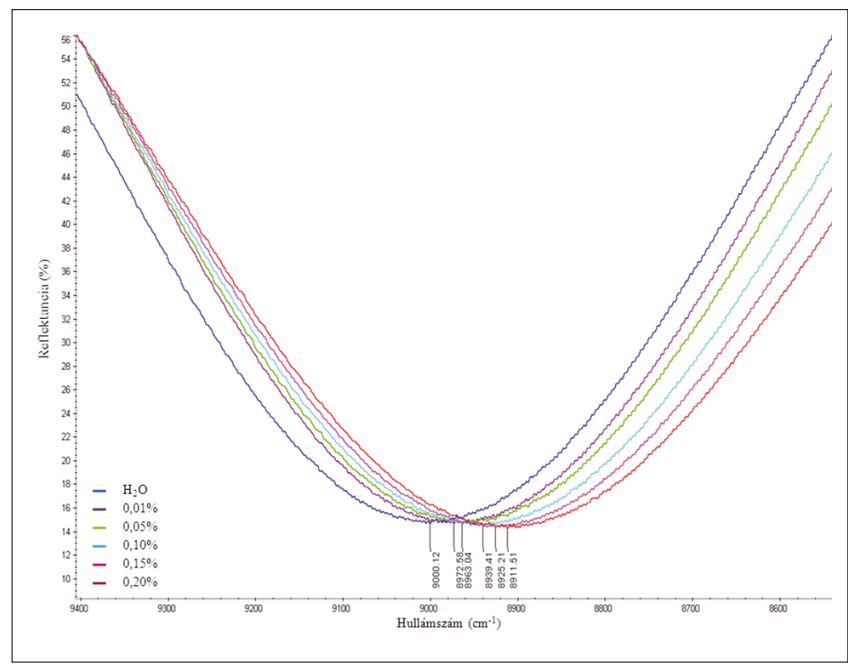

2. ábra: Különböző koncentrációjú formaldehid-oldatok FT-SPR spektrumai

0,01\%, 0,05\%, 0,1\%, 0,15\%, 0,2\%-os formaldehid-oldat. Az adatok az ábrán színskála segítségével is fel vannak tüntetve.

Minden egyes görbén megkereshető az a hullámszámérték, amelyhez minimális reflektancia-érték (nagyságrendileg 15\%) párosul. Ezen adatok a különböző oldatok esetén mérhető rezonanciahullámhossz-értékek. $A z$ ábrákon is feltüntetett értékek a desztillált víztől a $0,2 \%$-os töménységű formaldehid-oldat felé haladva: $9000,12 \mathrm{~cm}^{-1}, 8972,58 \mathrm{~cm}^{-1}, 8963,04 \mathrm{~cm}^{-1}, 8939,41 \mathrm{~cm}^{-1}$, $8925,21 \mathrm{~cm}^{-1}, 8911,51 \mathrm{~cm}^{-1}$.

A metakrilsav-oldat hígítási sorral végzett kísérletek az előző fejezetben leírtakhoz hasonlóan kerültek kivitelezésre. A 3. ábrán láthatók az oldatok egyéni FT-SPR spektrumai, az egyes görbék balról jobbra haladva: desztillált víz, $0,01 \%, 0,05 \%, 0,1 \%, 0,15 \%$ és $0,2 \%$-os metakrilsav-oldat. A különböző elegyek esetében az adatok könnyebb beazonosíthatóságát az ábrán színskála is segíti.

Ebben az esetben is megkereshető mindegyik görbén az a hullámszámérték, amelyhez a már említett minimális visszaverö-képesség (metakrilsavval végzett mérések esetén körülbelül $16 \%$ ) társul, ez az érték adja meg az adott koncentrációjú oldathoz tartozó rezonancia-hullámszámot. $A z$ ábrákról is leolvasható értékek desztillált víztől az egyre növekvő töménységű metakrilsav-oldatok felé haladva: $8990,66 \mathrm{~cm}^{-1}, 8976,87 \mathrm{~cm}^{-1}$, $8962,83 \mathrm{~cm}^{-1}, 8948,83 \mathrm{~cm}^{-1}, 8935,14 \mathrm{~cm}^{-1}$.

Mindkét hígítási sor esetében kiszámolható, hogy egy meghatározott koncentrációjú oldat áramoltatása milyen mértékben változtatja meg a rezonancia-hullámszámot a tiszta oldószerrel mért értékhez képest. A különböző töménységú formaldehid-oldatoknál kalkulált változások egész értékekre kerekítve: $0,01 \%$-os oldat esetén $27 \mathrm{~cm}^{-1}$, $0,05 \%$-os oldat esetén $37 \mathrm{~cm}^{-1}, 0,1 \%$-os oldat esetén $61 \mathrm{~cm}^{-1}, 0,15 \%$-os oldat esetén $75 \mathrm{~cm}^{-1}, 0,2 \%$-os oldat esetén $88 \mathrm{~cm}^{-1}$. Hasonlóképpen a metakrilsav hígítási

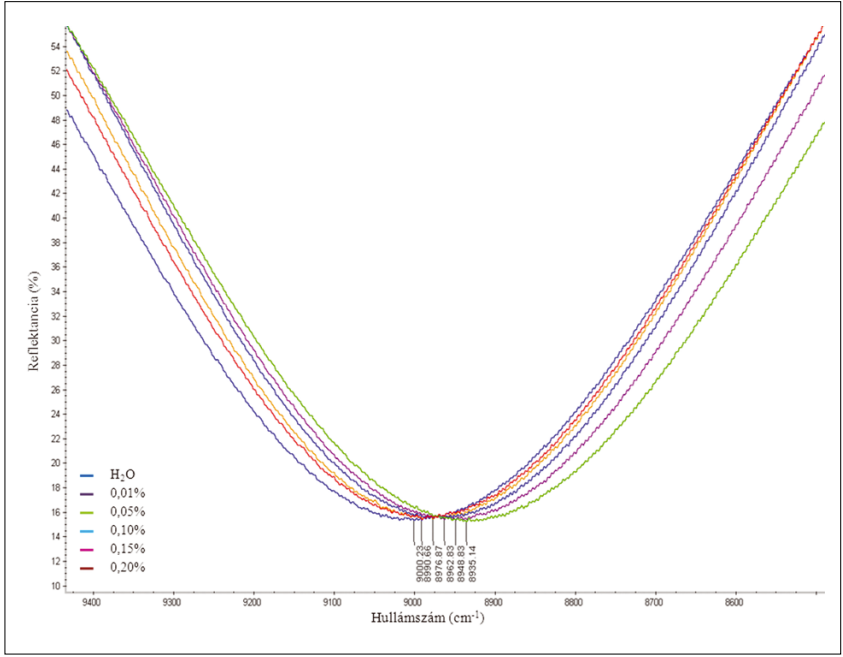

3. ábra: Különböző koncentrációjú metakrilsav-oldatok FT-SPR spektrumai

sor esetében számított eltolódások egész értékekre kerekítve: $0,01 \%$-os oldat esetén $9 \mathrm{~cm}^{-1}, 0,05 \%$-os oldat esetén $23 \mathrm{~cm}^{-1}, 0,1 \%$-os oldat esetén $37 \mathrm{~cm}^{-1}, 0,15 \%$-os oldat esetén $51 \mathrm{~cm}^{-1}, 0,2 \%$-os oldat esetén $65 \mathrm{~cm}^{-1}$. Minden egyes változás negatív irányba következett be, tehát valamennyi oldat esetében alacsonyabb rezonan-
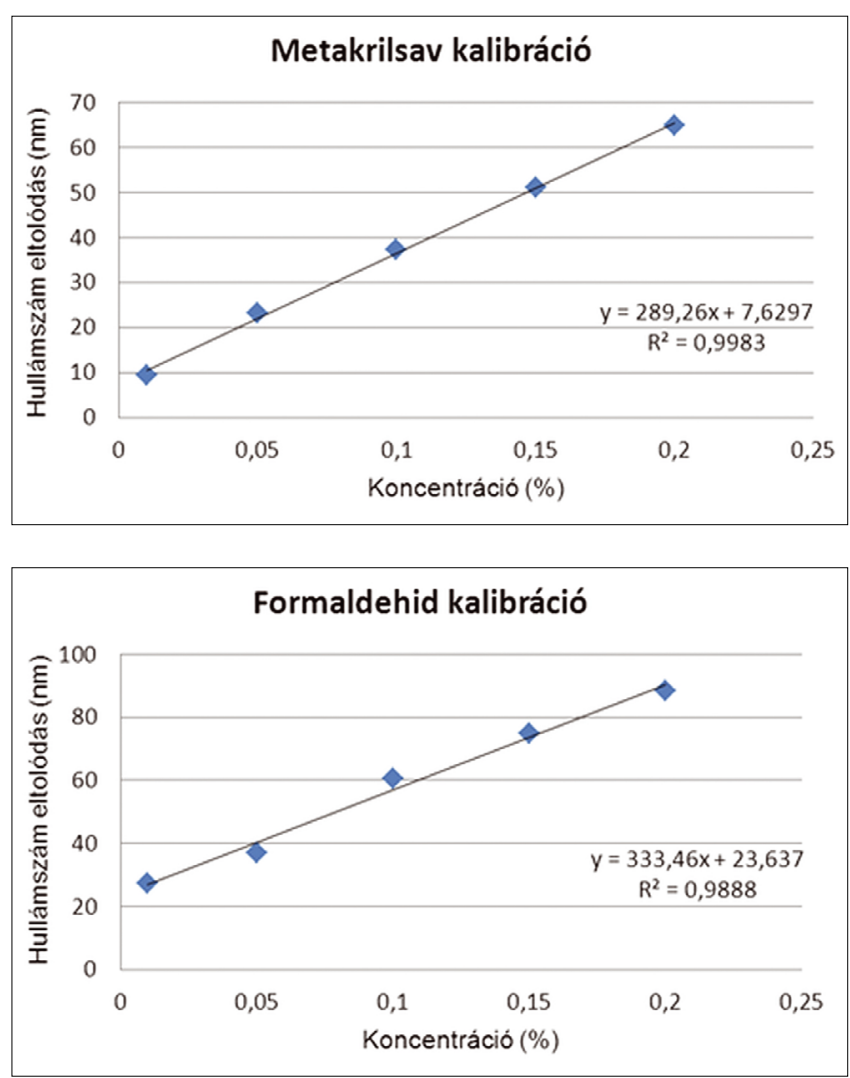

4. ábra: Formaldehid- és metakrilsav-oldatok kalibrációs egyeneseinek meghatározása FT-SPR módszer segítségégével 
ciahullámhossz-értéket kaptunk az oldószerrel mért eredményhez képest. Az adatok alapján megállapítható, hogy minél töményebb oldatot áramoltatunk az aranyfilm fölött, annál nagyobb mértékben csökken a rezonancia-hullámszám. A bevezetőben leírtak alapján a törésmutató egyre nagyobb változása pedig egyre kifejezettebb változásokat idéz elő a fém külső elektronjainak állapotában, amelyet a rezonancia-hullámszám egyre jelentősebb eltolódásán keresztül detektálhatunk.

Megfigyelhető továbbá, hogy az általunk vizsgált anyagok esetében az adott oldatok rezonancia-hullámszámváltozása lineáris arányosságban van a folyadékcellába kerülő oldat töménységével. Ez a megállapítás lehetővé teszi, hogy egy adott mintában lévő molekulát kvantitatív módon is kimutassunk. A kapott értékekből kalibrációs egyenes meghatározására nyílik lehetőségünk, amely alapján ismeretlen töménységű oldat koncentrációja egyszerűen kiszámolható. A kalibrációs egyenesek, valamint a pontok egyenes körüli szórása formaldehid, illetve metakrilsav-oldatok esetén a 4. ábrán láthatók.

\section{Megbeszélés}

Az FT-SPR mérési módszer specifikus kémiai kötések vizsgálatát is lehetővé teszi. Ezt kihasználva kétmolekulás receptor-ligandum vagy antigén-antitest kölcsönhatások reakciókinetikájának feltérképezése is lehetővé válik. Mindamellett, hogy néhány anyag közvetlenül kötődik az aranyfelszínhez, specifikus kötések vizsgálatához a legtöbb esetben az SPR-chip felületi módosítása szükséges. A felszíni rétegek kialakítása ugyanis könnyebben ellenőrizhető azáltal, hogy az aranyréteget először egy monomolekuláris réteggel borítjuk be, amely megfelelő funkciós csoportokat biztosít a további kapcsolatok kialakításához. A legnépszerübb szemlélet szerint először egy alkán-tiol komponensen keresztül úgynevezett „önszerveződő monoréteges struktúra” (selfassembled monolayer, SAM) kerül kialakításra: a tiolcsoport kötést létesít az aranyfelszínnel, míg a molekula másik végén lévő funkciós csoport lehetőséget biztosít további anyagok kapcsolódásához. Az alkán-tiolok különböző funkciós csoportokkal rendelkezhetnek, mint például amin- vagy karboxilcsoport. A SAM-ek tovább módosíthatók bifunkcionális kapcsoló molekulákkal, hogy különböző funkciós molekulákkal fedett felszínt képezzenek. A kialakított funkciós csoporthoz kémiailag köthető (immobilizálható) a specifikus kölcsönhatás egyik komponense, míg a másik oldat formájában áramoltatható a módosított felület felett. Amennyiben a két komponens stabil komplexet képez egymással, akkor a felületen a tömegkoncentráció - ezáltal a törésmutató - megnövekszik, és ez a változás jól detektálható $[16,18]$.

Az általunk vizsgált modellrendszer még nem az invivo helyzetet szimulálja, hanem az említett fogászati allergének kötődését, vizsgálhatóságát kívánta tanulmá- nyozni, ezért biológiai minták (például fehérjék) kötődési sajátosságainak meghatározására még nem alkalmas. Megfelelő chip kialakításával, az előző bekezdésben említett felületkezelés segítségével azonban specifikus kölcsönhatások vizsgálatára, így biológiai minták allergéntartalmának közvetlen meghatározására, allergének azonosítására, illetve allergiás reakciók részlépéseinek felderítésére is alkalmassá válhat. Napjainkban az ipar fejlődése számos különböző kémiailag módosított - például karboximetil, polikarboxilát vagy tetraetilén-glikol felszínnel rendelkező - SPR-chipek használatát is lehetővé teszi. Ezáltal a vizsgált fogászati allergénekre - formaldehidre vagy akár metakrilsavra specifikus vizsgálatok is lehetővé válhatnak, amelyek a jövőbeli kutatásaink elsődleges céljait képezik. Természetszerúleg az FT-SPR módszer specifikus szükségleteit figyelembe véve, a gyakorlati beavatkozások helyszínéül szolgáló rendelőkben az elterjedésére kevésbé lehet számítani. Nagy érzékenysége és flexibilis vizsgálati lehetőségeinek figyelembevételével viszont az allergia különböző részfolyamatainak felderítésében, illetve megfelelő módszerek kidolgozását követően akár az allergiás páciensek szürésében is szerepe lehet. Egy elöre meghatározott protokoll szerint gyüjtött/kezelt, például nyálmintát alapul véve, lehetőség nyílhat egy a szervezetre nézve plusz terhelést nem jelentő vizsgálati típus kialítására, melyet egy jól felszerelt diagnosztikai központban már könnyen, a meglévő módszerek mellett alkalmazhatnak. Mindemellett természetesen a mai modern készülékek és irányvonalak figyelembevételével akár az is elképzelhető, hogy a módszer érzékenységét, egy kisméretű, hordozható készülékbe történő integrálás útján használják ki. Ezáltal akár helyben megvalósítható mérések és vizsgálatok is kivitelezhetővé válhatnak, melyet megfelelö körülmények között akár helyben értékelni lehet, vagy a mért értékeket, az egyre szélesebb körű informatikai hálózatok terjedésével könnyedén szakértői elemzésre lehet továbbítani.

A vizsgálatok alapjául szolgálhat, hogy az általunk bemutatott eredmények alapján, 0,1\%-os koncentrációváltozását formaldehid-oldat esetén $61 \mathrm{~cm}^{-1}$-es, metakrilsav oldat esetén $37 \mathrm{~cm}^{-1}$-es változást idéz elő a rezonancia-hullámszámban. Figyelembe véve a tényt, hogy az FT-SPR spektroszkóp elméleti hullámszám-pontossága $0,01 \mathrm{~cm}^{-1}$, a készülék képes lehet egy adott vegyület akár százezrelékes nagyságrendű koncentráció változását is detektálni. Ez a tulajdonság lehetővé teszi egy adott oldatban lévő molekula kiemelkedő érzékenységü kvalitatív meghatározását.

A módszer elvi alapjai megegyeznek a tradicionális SPR-technika elvi alapjaival, így a hagyományos SPR spektroszkópiában felmerülő nehézségek az általunk vizsgált eljárásnál is nehézséget jelentenek. A technikával kapcsolatban felmerülő nehézségek többek között: i) az SPR-jelenség vizsgálatára alkalmas, detektorként alkalmazható fémek limitált száma; ii) a törésmutatóérték hőmérséklet-függése; iii) a nem specifikus interakciók hatására is kialakuló SPR-válasz. A mérési kö- 
rülmények pontos meghatározásával és a megfelelöen gondos minta-előkészítéssel azonban minimalizálni lehet azokat a tényezőket, amelyek a vizsgálati szándéktól eltérően befolyásolják a kísérleti eredményeket.

\section{Köszönetnyilvánítás}

Bakó József publikációt megalapozó kutatása a TÁMOP4.2.4.A/2-11-1-2012-0001 azonosító számú Nemzeti Kiválóság Program - Hazai hallgatói, illetve kutatói személyi támogatást biztosító rendszer kidolgozása és müködtetése országos program címú kiemelt projekt keretében zajlott. A projekt az Európai Unió támogatásával, az Európai Szociális Alap társfinanszírozásával valósul meg. A kutatócsoport többi tagjának munkája és infrastruktúrája a TÁMOP-4.2.2.A-11/1/KONV-2012-0036 projekt támogatásával valósult meg.

\section{Irodalom}

1. Ahlgren C, Axéll T, Möller H, Isaksson M, Liedholm R, Bruze M: Contact allergies to potential allergens in patients with oral lichen lesions. Clin Oral Investig. 2014; 18(1): 227-237.

2. BaKo J, Kelemen M, Hegedus Cs: Analysis of benzoyl-peroxide and formaldehyde as dental allergens by FT-SPR method. IOP Conf. Ser.: Mater. Sci. Eng. 47012001 DOI 10.1088/1757-899X/47/1/012001.

3. Bettencourt AF, Neves CB, de Almeida MS, Pinheiro LM, Oliveira SA, LOPES LP, CASTRO MF: Biodegradation of acrylic based resins: A review. Dent Mater. 2010; 26(5): 171-180.

4. Boujday S, Méthivier C, Beccard B, Pradier C-M: Innovative surface characterization techniques applied to immunosensor elaboration and test: Comparing the efficiency of Fourier transform-surface plasmon resonance, quartz crystal microbalance with dissipation measurements, and polarization modulation-reflection absorption infrared spectroscopy. Anal Biochem. 2009; 387(2): 194-201.

5. Brockman JM, Nelson BP, Corn RM: Surface plasmon resonance imaging measurements of ultrathin organic films. Annu Rev Phys Chem. 2000; 51: 41-63.

6. Corn RM, Weibel SC: Fourier Transform Surface Plasmon Resonance. Mid-infrared External Reflection Spectroscopy 2002; 1057-1064.
7. Frutos AG, Weibel SC, Corn RM: Near-Infrared Surface Plasmon Resonance Measurements of Ultrathin Films. 2. Fourier Transform SPR Spectroscopy. Anal. Chem. 1999; 71: 39353940.

8. Hashimoto K-I, Naganuma K, Yamashita Y, Ikebe T, Ozekı S: A case of mucositis due to the allergy to self-curing resin. Oral Science International, 2014; 11(1): 37-39.

9. Kurata S, Morishita K, Kawase T, Umemoto K: Cytotoxic effects of acrylic acid, methacrylic acid, their corresponding saturated carboxylic acids, HEMA, and hydroquinone on fibroblasts derived from human pulp. Dent Mater J. 2012; 31(2): 219-225.

10. Liedberg B, Nylander C, Lundström I: Biosensing with surface plasmon resonance--how it all started. Biosens Bioelectron. 1995; 10(8): I-IX.

11. Lyapina M, Dencheva M, Krasteva A, Tzekova M, Kisselova-Yaneva A: Concomitant contact allergy to formaldehyde and methacrylic monomers in students of dental medicine and dental patients. Int J Occup Med Environ Health. 2014; 27(5): 797-807.

12. Pfeifer, $P$, Aldinger, U, Schwotzer, G, Diekmann, S, Steinrücke, P: Real time sensing of specific molecular binding using surface plasmon resonance spectroscopy Sensors and Actuators B. Chemical. 1999; 54(1): 166-175.

13. Sofou A, Tsoupi I, Emmanouil J, Karayannis M: HPLC determination of residual monomers released from heat-cured acrylic resins. Anal Bioanal Chem. 2005; 381(7): 1336-1346.

14. Szaloki M, Vitalyos G, Harsfalvi J, Hegedus Cs: Binding of leachable components of polymethyl methacrylate (PMMA) and peptide on modified SPR chip. IOP Conf. Ser.: Mater. Sci. Eng. 47012002 DOI 10.1088/1757-899X/47/1/012002.

15. TAN GK, Dinnes DL, Butler LN, CoOper-White JJ: Interactions between meniscal cells and a self assembled biomimetic surface composed of hyaluronic acid, chitosan and meniscal extracellular matrix molecules. Biomaterials. 2010; 31(23): 61046118.

16. Thébault P, Boujday S, Sénéchal H, Pradier CM: Investigation of an allergen adsorption on amine- and acid-terminated thiol layers: influence on their affinity to specific antibodies. J Phys Chem $B$. 2010; 114(32): 10612-10619.

17. Vallittu PK, Miettinen V, Alakuijala P: Residual monomer content and its release into water from denture base materials. Dent Mater. 1995; 11(6): 338-342.

18. Wei J, Yan L, Hu X, Chen X, Huang Y, Jing X: Non-specific and specific interactions on functionalized polymer surface studied by FT-SPR. Colloids Surf B Biointerfaces. 2011; 83(2): 220-228.

19. Yap AU, Lee HK, Sabapathy R: Release of methacrylic acid from dental composites. Dent Mater. 2000; 16(3): 172-179. 
Bakó J, Kelemen M, Szalókı M, Vitályos G, Radics T, Hegedüs C

Analysis of the binding properties of leachable components of base plate by Fourier-Transform Surface Plasmon Resonance (FT-SPR) method

\begin{abstract}
In parallel with the emergence of new dental materials the number of allergic diseases is continuously increasing. Extremely small quantities of the allergens are capable to inducing an allergic reaction. Therefore it is particularly important to examine these materials as antigens and investigate their binding properties to proteins (e.g. formaldehyde, methacrylic acid, benzoyl-peroxide...). The Fourier Transform Surface Plasmon Resonance Spectroscopy (FT-SPR) is a suitable examination method for this type of procedure. FT-SPR measurement is performed at a fixed angel of incident light, and reflectivity is measured over a range of wavelength in the near infrared. The advantages of this method are the outstanding sensitivity, the label-free detection capability and the possibility of the real-time testing procedure.

Formaldehyde and methacrylic acid are among the most common dental allergens. In our study we examined these molecules by FT-SPR spectroscopy. The aim of this work was to investigate the suitability of this method to the detection of these materials, with special focuses on the analysis and evaluation concentration-dependent measurements.

Different concentrations $(0,01 \%-0,2 \%)$ of formaldehyde and methacrylic acid solutions were measured. The individual spectra were measured for all of the solutions, and calibration curves were calculated for the materials for the possibility of the determination of an unknown concentration. The results confirmed that the method is theoretically capable to detect hundred-thousandths scale concentration-changes in the solution flowing above the SPR-chip. The concentrationdependent studies had proved that the method capable to measure directly these materials and can provide appropriate calibration for quantitative determination. These experiments show the broad applicability of the FT-SPR method, which can greatly facilitate the mapping and understanding of biomolecular interactions in the future.
\end{abstract}

Keywords: formaldehyde, methacrylic acid, allergens, Fourier Transform Surface Plasmon Resonance Spectroscopy (FT-SPR)

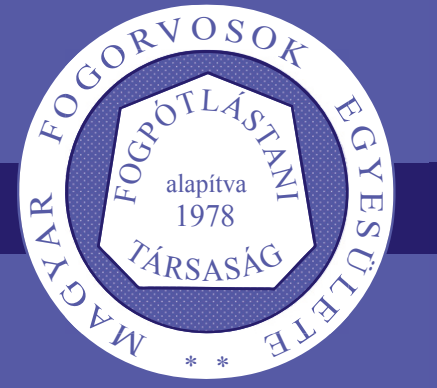

\title{
FOGPÓTLÁSTANI NAPOK Pécs, 2015. szeptember 24-26.
}

Magyar Fogorvosok Egyesưletének Fogpótlástani Társasága XXI. kongresszus és továbbképzö tanfolyam

Az érem két oldala: Aktuális témakörök a fogpótlástanban a fogorvos és a fogtechnikus szemszögéböl Továbbképző tanfolyam fogorvosok és fogtechnikusok számára 2015. szeptember 24.

Implantációs és digitális fogpótlástan a 21. században A Magyar Fogorvosok Egyesületének Fogpótlástani Társaságának XXI. kongresszusa 2015. szeptember 25.

A fogpótlástan korszerủ anyagai és technikái Továbbképző tanfolyam fogorvosok számára 2015. szeptember 26.

Prof. Dr. Hegedüs Csaba, elnök MFE Fogpótlástani Társasága 